\title{
LE PRESIDENT/THE PRESIDENT
}

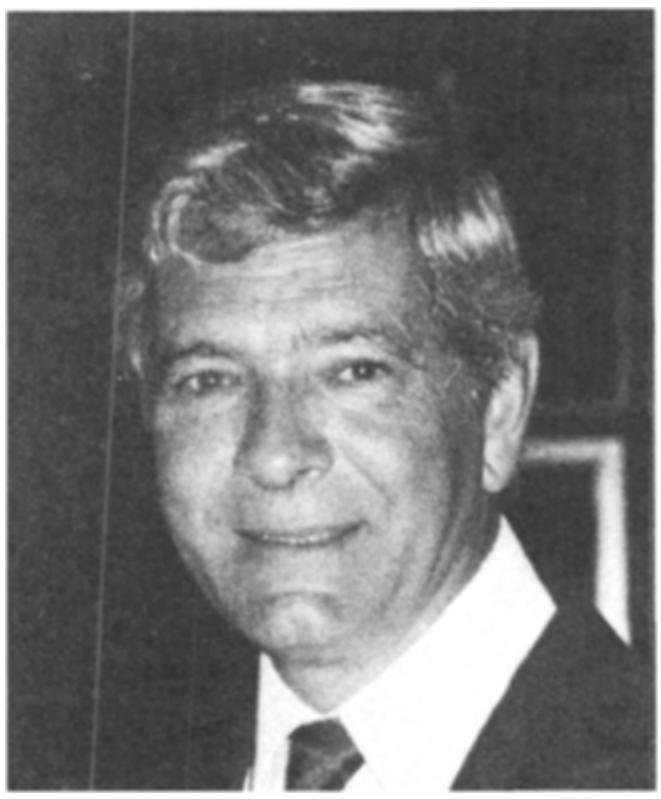

J.-C. Pouliot, B.A., M.D., C.S.P.Q., F.R.C.P.(C)

Le docteur J.-C. Pouliot de Québec a assumé la présidence de la Société Canadienne des Anesthésistes au cours du congrès annuel tenu à Halifax en juin 1981.

Après avoir gradué en Médecine à l'Université Laval, le docteur Pouliot completera ses études en anesthésie à l'Hôpital de l'Enfant-Jésus, puis à l'Université de Toronto. Par la suite, il fut boursier McLaughlin et poursuivit ses études à Londres, Angleterre (Westminster Hospital et Royal College of Surgeons).

Assistant dans le Département d'anesthésie de l'Hôpital de l'Enfant-Jésus depuis 1962, il a par la suite été nommé professeur agrégé en anesthésie à l'Université Laval. Il a été membre du Comité des Examinateurs en anesthésie du Collège Royal des Médecins et Chirurgiens du Canada. Le docteur Pouliot est actuellement chef du Département d'anesthésie-réanimation de l'Hôpital de l'Enfant-Jésus.

De 1973 à 1977, il a été membre du Conseil puis membre de l'Exécutif de l'Association des Anesthésistes-Réanimateurs du Québec. En 1975, il fut nommé délégué de l'Association des Anesthésistes-Réanimateurs du Québec au sein du Conseil de la Société Canadienne des Anesthésistes et en 1978, il a agi à titre de représentant
Dr. J.-C. Pouliot of Quebec was installed as President of The Canadian Anaesthetists' Society at the Annual Meeting in Halifax in June 1981.

Dr. Pouliot graduated in Medicine from Laval University in 1957 and, following internship, completed anaesthesia training at l'Enfant-Jésus Hospital, Quebec, and at the University of Toronto. He was then awarded a McLaughlin Fellowship and undertook further training at Westminster Hospital, London, England, and at the Royal College of Surgeons, England.

In 1962 he became assistant in the Department of Anaesthesia at l'Enfant-Jésus Hospital and then Associate Professor in Anaesthesia at Laval University. He has been a member of the Board of Examiners of the Royal College of Physicians and Surgeons of Canada. He is Director of the Department of Anaesthesia at l'Enfant-Jésus Hospital.

From 1973 to 1977 , he was an elected member of the Council and the Executive of the Association of Anaesthetists of Quebec. In 1975, he was appointed to the Council of the Canadian Anaesthetists' Society as representative of the Quebec Division and in 1978 became a representative of Council on the Executive Committee. He was 
du Conseil auprès du bureau de la Société. Il a elected 2nd Vice-President in 1979, and Ist occupé le poste de $2^{\circ}$ vice-président en 1979 et de Vice-President in 1980.

$1^{\text {"rr }}$ vice-président en 1980.

Dr. Pouliot is married to Suzanne Bolduc; they

Le docteur Pouliot est marié à Suzanne Bol- have four daughters. Dr. Pouliot's other interests

duc; ils ont quatre filles. Leurs principaux in- include classical music, tennis, riding, hunting térêts incluent le goût pour la musique classique, and skiing.

le tennis, l'équitation, la chasse à courre et le ski. 